\title{
THE EFFECT OF AGMATINE ON SPIKE-AND-WAVE DISCHARGES IN A GENETIC MODEL OF ABSENCE EPILEPSY
}

\author{
AGMATININ GENETIK BIR ABSANS EPILEPSI MODELINDE DIKEN-VE-DALGA \\ DEŞARJLAR ÜZERINE ETKISI
}

\author{
Özlem AKMAN ${ }^{1}$ (D), Tijen UTKAN² (D), Feyza ARICIOĞLU³ (D), Nurbay ATEŞ ${ }^{4}$ (D), Ayşe KARSON ${ }^{4}$ (D) \\ 'Demiroğlu Bilim University, Faculty of Medicine, Department of Physiology, Istanbul, Turkey \\ ${ }^{2}$ Kocaeli University, Faculty of Medicine, Department of Pharmacology, Kocaeli, Turkey \\ ${ }^{3}$ Marmara University, Faculty of Pharmacy, Department of Pharmacology, Istanbul, Turkey \\ ${ }^{4}$ Kocaeli University, Faculty of Medicine, Department of Physiology, Kocaeli, Turkey
}

ORCID IDs of the authors: Ö.A. 0000-0002-0610-7955; T.U. 0000-0001-5848-3680; F.A. 0000-0003-4669-9382;

N.A. 0000-0003-1272-9360; A.K. 0000-0003-4909-4012

Cite this article as: Akman O, Utkan T, Aricioglu F, Ates N, Karson A. The effect of agmatine on spike-and-wave discharges in a genetic model of absence epilepsy. J Ist Faculty Med 2022;85(1):15-21. doi: 10.26650/IUITFD.904146

\section{ABSTRACT}

Objective: Studies on the actions of exogenous agmatine in experimental models have shown its anti-convulsant effects. However, there are no findings regarding the influence of agmatine on absence epilepsy. Therefore, we investigated the effects of the agmatine in the occurrence of spike-and-wave discharges (SWDs) in the Wistar Albino Glaxo Rijswijk rats (WAG/Rij) model of genetic absence epilepsy.

Materials and Methods: Three different doses (20, 40 or 80 $\mathrm{mg} / \mathrm{kg}$ ) of agmatine or saline were administered intraperitoneally to the adult WAG/Rij rats, and electroencephalography (EEG) was recorded for 2.5 hours. The number and the mean and cumulative durations of SWDs were measured. The SWD frequency characteristics were quantified by means of average power-spectra of the first $2^{\text {nd }}$ segments of the SWD complexes before and after the effective dose of agmatine.

Results: Agmatine, administered $80 \mathrm{mg} / \mathrm{kg}$ systemically, temporarily increased the number and cumulative duration of SWDs compared with saline injected WAG/Rij rats. This effect of agmatine, however, was not associated with any change in the frequency characteristics of the SWD complexes. There was no effect on neither the incidence nor the cumulative duration of SWDs when agmatine administered in lower doses (20 or 40 mg/kg).

Conclusion: Higher doses of agmatine temporarily and slightly increase the incidence of SWDs in WAG/Rij rats, which may suggest its possible aggravating activity in absence epilepsy patients through its activity on adrenergic, serotonergic and AMPA receptors.

Keywords: Agmatine, absence epilepsy, wistar albino glaxo rijswijk rats

\begin{abstract}
ÖZET
Amaç: Deneysel modellerde yapılan araştırmalar ekzojen agmatinin anti-konvülzan etkilerinin olduğunu göstermiştir. Ancak, agmatinin absans epilepsisi üzerindeki etkisine dair herhangi bir veri bulunmamaktadır. Bu çalışmada, agmatinin absans epilepsinin genetik bir modeli olan Wistar Albino Glaxo Rijswijk (WAG/ Rij) ırkı sıçanlarda Diken-ve-Dalga Deşarjlar (DDD) üzerine olan etkilerini araştırdık.
\end{abstract}

Gereç ve Yöntem: Yetişkin WAG/Rij sıçanlarda periton içine 3 farklı doz agmatin (20, 40 ya da $80 \mathrm{mg} / \mathrm{kg}$ ) ya da serum fizyolojik uygulandı ve 2,5 saat boyunca elektroensefalografi (EEG) kaydedildi. Elde edilen EEG kayıtlarında DDD'lerin sayısı, ortalama ve kümülatif süreleri değerlendirildi. DDD'lerin frekans özellikleri, etkili agmatin dozundan önce ve sonra, DDD aktivitesinin ilk iki saniyelik bölümlerinin ortalama güç spektrumları hesaplanarak karşılaştırıldı.

Bulgular: WAG/Rij sıçanlara sistemik olarak uygulanan 80 mg/kg agmatin DDD'lerin sayısını ve kümülatif süresini serum fizyolojik uygulanan gruba göre geçici olarak arttırdı. Ancak, agmatinin bu etkisi DDD'lerin frekans özelliklerindeki bir değişiklikle ilişki bulunmadı. Daha düşük dozlarda uygulanan agmatin (20 veya $40 \mathrm{mg} / \mathrm{kg}$ ) ise DDD'lerin sayı ve süresine değişikliğe yol açmadı.

Sonuç: Yüksek doz agmatin WAG/Rij ırkı sıçanlarda DDD insidansını geçiçi olarak arttırmaktadır. Bu sonuçlar, agmatinin absans epilepsisi hastalarında adrenerjik, serotonerjik ve AMPA reseptörleri aracılığı ile olası bir kötüleştirici etki gösterebileceğini işaret etmektedir.

Anahtar Kelimeler: Agmatin, absans epilepsi, wistar albino glaxo rijswijk ırkı sıçanlar

Corresponding author/iletişim kurulacak yazar: ozlem.akman@demiroglu.bilim.edu.tr

Submitted/Başvuru: 27.03.2021 • Accepted/Kabul: 27.04.2021 • Published Online/Online Yayın: 22.11.2021 


\section{INTRODUCTION}

Typical absence seizures are accompanied by regular, synchronous, bilateral spike-and-wave discharges (SWDs) in the electroencephalogram (EEG) and occur in various genetic generalized epilepsy syndromes such as childhood absence epilepsy and juvenile absence epilepsy (1). The fully inbred strain Wistar-Albino-Glaxo from Rijswijk rats (WAG/Rij) is a well-validated model of generalized genetic epilepsy, and it has been developed to particularly model the childhood absence epilepsy (2). All individuals of this strain exhibit spontaneous SWDs in the EEG similar to those in human absence epilepsy $(1,3)$. This strain has been widely used in studies that aim to elucidate neurobiological mechanisms of SWDs and epileptogenesis and to evaluate the action mechanisms of antiepileptic drugs $(2,4)$.

Electrophysiological and EEG-fMRI studies in genetic rodent models and human subjects revealed that SWDs are generated within the cortico-thalamo-cortical neuronal networks $(1,4,5)$. Animal models demonstrated that SWDs begin within the focal, hyperexcitable area within deep layers of the perioral somatosensory cortex (S1 po) before propagating to the thalamic nuclei $(6,7)$. Electrophysiological studies have shown that sensory relay nuclei of the thalamus such as the ventral-postero-medial (VPM) and the posterior thalamic nuclei (Po) and the GABA-ergic reticular thalamic nucleus (RTN), the main inhibitory nucleus of the thalamus, seem to play major roles in the generation of SWDs $(2,8)$. The thalamus is reciprocally connected with the cortex through glutamatergic excitatory pathways, while both thalamo-cortical and cortico-thalamic pathways have collateral glutamatergic projections to the GABA-ergic RTN $(2,4)$. Due to this neurochemical profile, both ionotropic and metabotropic receptors of both neurotransmitter systems are widely expressed in the cortex and the thalamus, and strongly influence the occurrence of SWDs $(2,4,9,10)$. However, it has also been demonstrated that monoamines such as noradrenalin, adrenalin and serotonin also modulate the cortico-thalamo-cortical circuitry, hence affecting the occurrence of SWDs (1,11-13).

Agmatine, an endogenous polyamine naturally synthesized from amino acid L-arginine by the enzyme arginine decarboxylase, is found in the synaptic terminals and cytoplasm of neurons and has been suggested to modulate many ion channels, receptors and downstream signaling pathways (14-16). Although daily diet provides only small amounts of polyamines, high levels of agmatine are present in fermented alcoholic beverages and in protein-rich foods (17). Agmatine activates $\mathrm{G}$-protein coupled receptors (GPCRs), including $\alpha 2$-adrenergic $\left(\alpha_{2 A} R_{S}\right)$ and serotonergic (5- $\mathrm{HT}_{1 \mathrm{~A} / 1 \mathrm{~B}}$ and $5-\mathrm{HT}_{2}$ ) receptors. In addition to its interaction with AMPA type glutamate receptors $\left(A M P A R_{S}\right)$ and blocking effect on NMDA type glutamate receptors $\left(\mathrm{NMDAR}_{\mathrm{S}}\right)$, it may also inhibit voltage-dependent calcium channels and nitric oxide synthase (NOS) (15,18-20).

Exogenous agmatine administration in experimental models revealed its neuroprotective effects in various neurological disorders (15). In addition to its anti-depressant, anti-oxidant and anti-inflammatory activity, agmatine also plays an anti-convulsant role against pentylenetetrazole (PTZ), maximal electroshock seizure (MES) and glutamate-induced seizure models in rodents (14,2022). However, there are no findings about the influence of agmatine in absence epilepsy. Considering its modulatory action on multiple neurotransmitter receptors and ion channels that may play a role in the pathophysiology of SWDs, we investigated the effects of agmatine on the SWDs in WAG/Rij rats.

\section{MATERIALS AND METHODS}

\section{Animal subjects and drugs}

Adult male WAG/Rij rats (6-8 month-old, weighing 240$350 \mathrm{~g})$ from the breeding colony of the Experimental Medical Research and Application Center of Kocaeli University were used in the experiments. The animals were housed under standard laboratory conditions on a 12/12 h light/ dark cycle (lights on at 7:00 a.m.) at $21 \pm 2^{\circ} \mathrm{C}$ and were allowed for free access to food and water in groups of 3-4 rats per cage. All experimental procedures were performed in accordance with the regulations of the Animal Research Ethics Committee in Turkey (Date: 06.06.2006, No:26220) and approved by Kocaeli University Animal Research Ethics Committee (protocol no: 1/3-2010).

The rats were randomly assigned in four groups $(n=9$, each group) in order to evaluate the dose-dependent effects of agmatine on the occurrence of SWDs. Group-1 (Saline) was treated with physiological saline only; Group-2 (Ag-20) received 20 mg/kg, Group-3 (Ag-40) 40 $\mathrm{mg} / \mathrm{kg}$ and Group-4 (Ag-80) $80 \mathrm{mg} / \mathrm{kg}$ agmatine. Agmatine sulphate (Sigma-Aldrich, St. Louis, MO, USA) was dissolved in physiological saline at the concentration of 20,40 or $80 \mathrm{mg} / \mathrm{ml}$ on the day of the experiment. Drugs or saline were injected intraperitoneally $(1 \mathrm{ml} / \mathrm{kg}$; ip) by using needles of $27 \mathrm{G}$. The doses of agmatine are based on the previous report (23).

\section{Stereotaxic surgery}

Stereotaxic surgery was performed as previously reported (24). Briefly, rats were anesthetized with ketamine (100 $\mathrm{mg} / \mathrm{kg}, \mathrm{ip})$ and xylazine (10 mg/kg, ip). When rats were fully anesthetized, the head was placed in a stereotaxic frame (Stoelting Model 51600, Stoelting Co., IL, USA) with the skull surface flat and bregma at $0 \mathrm{~mm}$. Epidural recording electrodes (MS333/2A; Plastic One, USA) were implanted on the frontal cortex (AP+2.0 mm and $L+3.5$ $\mathrm{mm}$ from bregma), occipital cortex (AP-6.0 $\mathrm{mm}$ and $\mathrm{L}+4.0$ 
$\mathrm{mm}$ from bregma), and the ground electrode was placed on the cerebellum after a longitudinal incision was cut over the skull. The electrodes were fixed to the skull with dental acrylic. All coordinates were obtained from the stereotaxic atlas of Paxinos and Watson (25). Following stereotaxic surgery, the animals were housed singly in Plexiglas cages and were allowed a one-week recovery period prior to EEG recordings.

\section{EEG recording and analysis}

One day before the experiment, the rats were habituated to the EEG recording system. The next day, after a 30 min adaptation period, the baseline EEG was recorded for one hour. Rats were injected with either a single dose of saline or with $20 \mathrm{mg} / \mathrm{kg}, 40 \mathrm{mg} / \mathrm{kg}$ or $80 \mathrm{mg} / \mathrm{kg}$ agmatine. The EEG was recorded continuously 150 min after the injections. To avoid the effects of circadian rhythm on the occurrence of SWDs, EEG recordings of all animals were performed at the same time of the day (between 9.00 a.m. and 12.30 p.m). The electrical activity of the cortex was amplified using Powerlab 8S System (ADI Instruments, UK) BioAmp ML-136 module, filtered between 0.3 and $120 \mathrm{~Hz}$, digitized at 1000 samples/s and recorded via LabChart v7.

A SWD complex was identified if its duration was longer than first second with a characteristic train of sharp large-amplitude spikes and slow waves (26). The first and last spike of an SWD complex with an amplitude at least twice the background amplitude of EEG was accepted as the SWD onset and offset. The number and mean duration of SWDs was measured for five periods of $30 \mathrm{~min}$ within the 150 min after the injection of the saline or the agmatine. The cumulative durations of SWDs were calculated as the sum of the individual durations of all SWDs present over $30 \mathrm{~min}$ intervals. The baseline SWDs were analyzed over one hour period, divided into two $30 \mathrm{~min}$ intervals. The sum of the two 30 min intervals was accepted as baseline level.
The spectral characteristics of SWDs were analyzed by computing the power spectra computed by using the Fast Fourier Transform (FFT) (The MathWorks MATLAB 9.5, Natick, USA) (27). The average power-spectra of the first $2^{\text {nd }}$ segments of the SWDs were computed for randomly selected 15 SWD complexes of each animal in each group.

\section{Statistical analyses}

All statistical analyses were performed with GraphPad Prism version 8.00 (GraphPad Software, San Diego, USA). Data were assessed for normality using a Shapiro-Wilk normality test. Results found to be normally distributed $(p>0.05)$ were expressed as mean \pm SEM. A two-way ANOVA (two factors: "Group" and "Time") followed by the post-hoc Bonferroni tests was used to analyze the number, mean duration and cumulative duration of SWDs among six-recording intervals and four experimental groups. For the comparison of the SWD spectra before and after the administration of the effective dose of agmatine $(80 \mathrm{mg} / \mathrm{kg})$ was carried out by a paired Student's t-test. The level of statistical significance was considered to be $p<0.05$. The results are presented as "FDFn, DFd = $F$ value, $p$ value" for ANOVA and " $p$ value" for post-hoc Bonferroni and t-tests.

\section{RESULTS}

All WAG/Rij rats displayed characteristic 7-9 Hz SWD complexes in their baseline EEG recordings (Figure 1). As seen in Figure 2 and 3, the number (measured as event number per 30 min period) and the cumulative duration of SWDs decreased over time in all conditions including saline injected group (Time effect: $F(5,192)=27.91$, $p<0.0001 ; F(5,192)=22.67, p<0.001$, respectively). There was also a significant effect of the group on both the number of SWDs and the cumulative duration of SWDs (Group effect: $F(3,192)=5.426, p=0.0013$ and $F(3,192)=3.876$, $\mathrm{p}=0.01$, respectively). The post-hoc Bonferroni tests

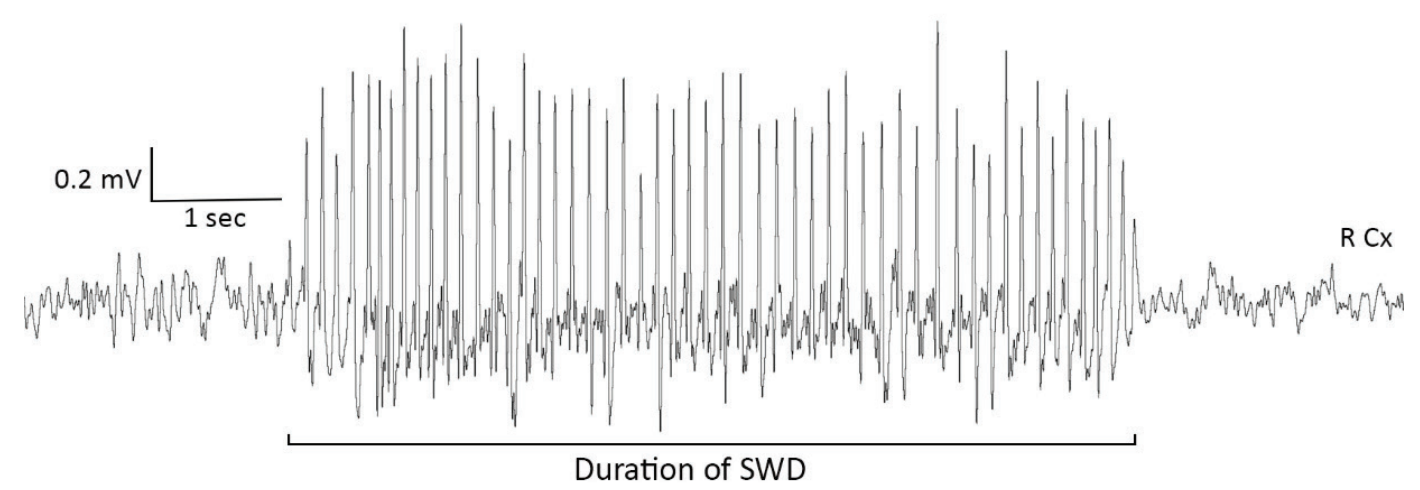

Figure 1: The representative electrographic pattern of an SWD recorded from the right cortex in a WAG/Rij rat. Voltage/time scale $0.2 \mathrm{mV} / 1 \mathrm{sec}$. R Cx: Right cortex 


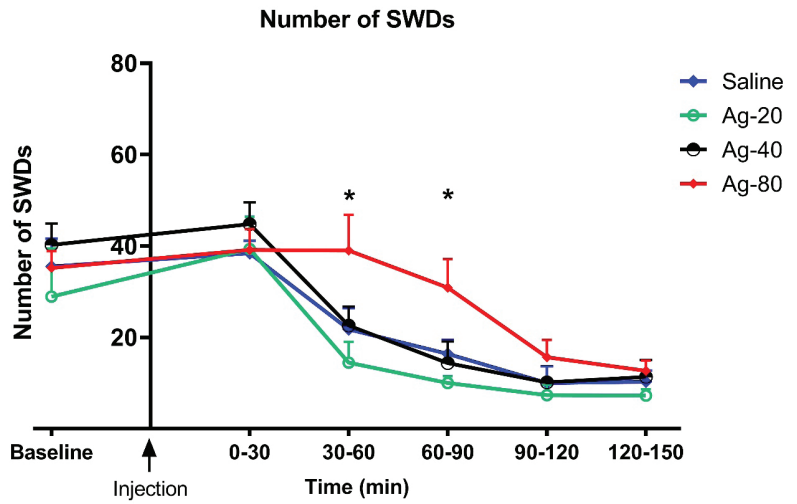

Figure 2: The effect of agmatine on the number of SWDs. The statistical analysis revealed a significant difference among four groups (Group effect: $F(3,192)=5.426$, $p=0.0013$ ). The post-hoc Bonferroni tests showed that this difference was due to the higher number of SWDs during the 30-60 min and 60-90 min post-injection recording periods $(p=0.0292)$ than saline treated WAG/Rij rats. Data are expressed as mean \pm SEM. *: $p<0.05$

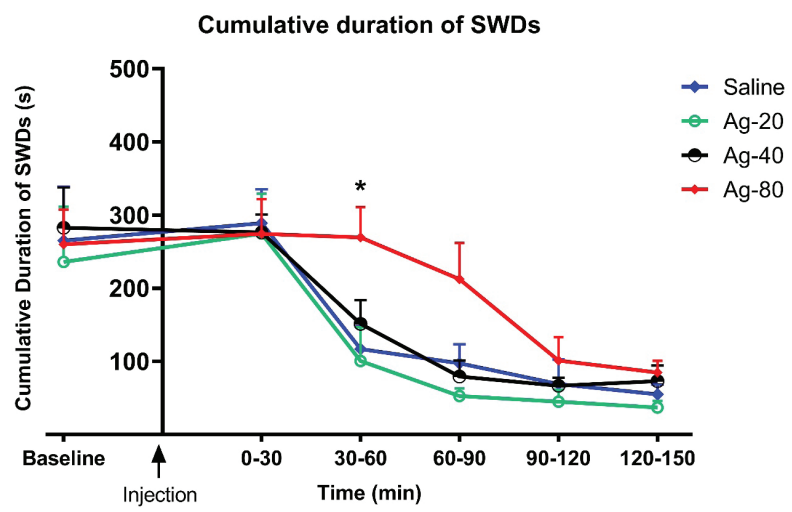

Figure 3: The effect of agmatine on the cumulative duration of SWDs. The statistical analysis revealed a significant difference among four groups (Group effect: $F$ $(3,192)=3.876, p=0.01)$. The post-hoc Bonferroni tests showed that this difference was due to the higher number of SWDs during the 30-60 min post-injection recording periods $(p=0.0205)$ than saline treated WAG/Rij rats. Data are expressed as mean \pm SEM. *: $p<0.05$

showed that the first effect was due to the higher number of SWDs during the 30-60 min and 60-90 min post-injection recording periods $(p=0.0292, p=0.0484$, respectively) than saline treated WAG/Rij rats. In line with this, the group effect on cumulative duration of SWDs was also due to the higher values obtained in the $\mathrm{Ag}-80$ group compared with the saline group during the $30-60$ post-injection recording period $(p=0.0205)$. No difference was observed among the groups in terms of the mean duration of SWDs (Group effect: $F(3,192)=2.409, p=0.0684$ ) (Figure 4).

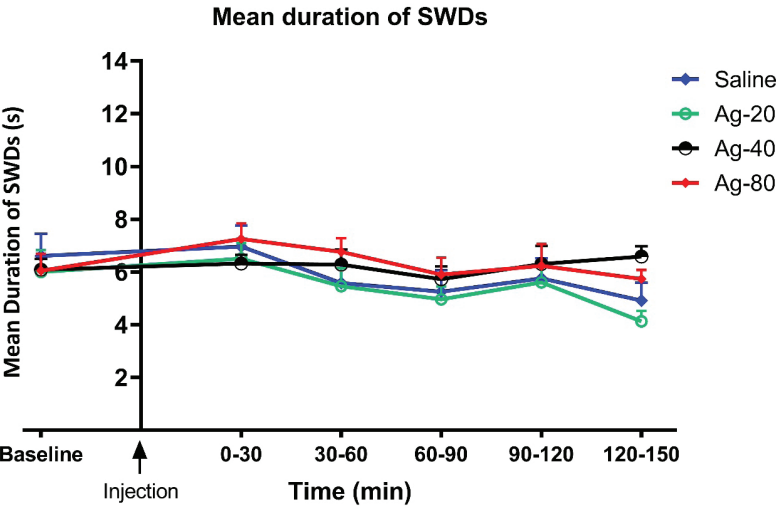

Figure 4: The effect of agmatine on the mean duration of SWDs. No difference was observed among the four groups (Group effect: $F(3,192)=2.409, p=0.0684$ ). Data are expressed as mean \pm SEM

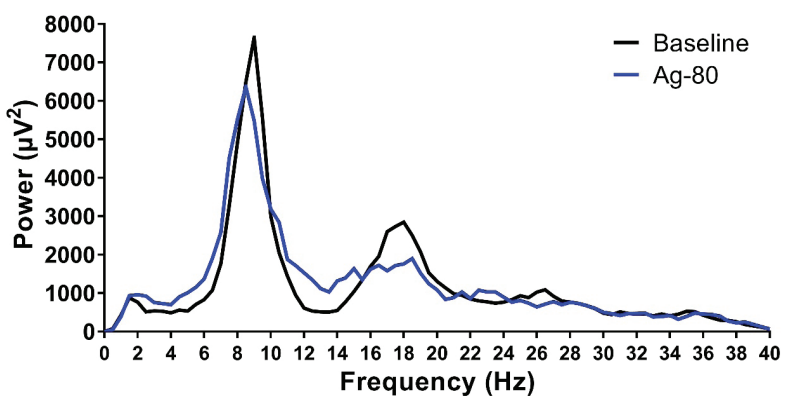

Figure 5: The power spectra of the first $2 \mathrm{~s}$ of the SWD complexes in the baseline and the $30-90$ min post-injection periods of the Ag-80 group

For the effective dose of agmatine, which introduced significant increase in the SWD number and cumulative duration, the frequency characteristics of the SWDs in the baseline and the $30-90$ min post-injection periods of the Ag-80 group were compared (Figure 5). The peak frequency in the power spectra computed by averaging the FFT magnitudes of the first $2^{\text {nd }}$ of 15 SWD segments in each condition was $8.83 \pm 0.12 \mathrm{~Hz}$ for baseline EEG and $8.61 \pm 0.14 \mathrm{~Hz}$ for SWD segments recorded $30-90$ min after $80 \mathrm{mg} / \mathrm{kg}$ agmatine injection. Paired t-test revealed no significant difference in the SWD frequencies between both periods $(p=0.225)$.

\section{DISCUSSION}

All WAG/Rij rats displayed characteristic 7-9 Hz SWD complexes in their baseline EEG recordings and a decrease in the number, and cumulative duration of SWDs was observed in all treatment groups including the injection of saline or various doses of agmatine along the 150 min EEG recordings. Such phenomenon was previously described in genetic absence epilepsy rats, and is assigned to the circadian change of the vigilance 
state along the day that influences the number of SWDs $(3,28,29)$. In order to exclude such circadian effect, posthoc comparisons were carried out between each of the agmatine administered groups and the saline applied control group, which displayed that agmatine, administered $80 \mathrm{mg} / \mathrm{kg}$ systemically, temporarily increased number (30-90 min after injection) and cumulative duration (30-60 min) of SWDs compared with the saline injected WAG/Rij rats. This effect of agmatine, however, was not associated with any change in the frequency characteristics of the SWD complexes.

Studies in genetic absence epilepsy models suggested that $A M P A R_{S}$ are recruited during absence seizures (4). Intracerebroventricular (ICV) injection of AMPA dose-dependently increased the incidence of SWDs $(30,31)$, whereas ICV injection or focal administration of AMPAR antagonists into S1po (initial site of SWDs) or RTN induced a dose-dependent decrease in the incidence and duration of SWDs in WAG/Rij rats $(9,30)$. Moreover, elevated AMPAR proteins, GluA1 and GluA2 in the somatosensory cortex plasma membrane of Genetic Absence Epilepsy Rats from Strasbourg (GAERS), another genetic model of absence epilepsy, have been reported, which suggested their contribution to hyperexcitability in somatosensory cortex and therefore to SWD generation (32). Agmatine is a neuromodulator capable of interacting with several types of glutamate receptors (20). For example, rapid antidepressant actions of agmatine have been shown to involve activation of $A M P A R_{S}$ due to the fast increase in AMPAR subunit GluA1 (33). Therefore, such a modulatory effect of agmatine on AMPARs may play a role in the aggravating effect of higher doses of agmatine on SWDs in our study.

Additionally, exogenous agmatine is able to increase monoamines and subsequently activate multiple postsynaptic GPCRs, including $\alpha_{2 \mathrm{~A}} \mathrm{R}_{\mathrm{S}}$ and $5-\mathrm{HT}_{1 \mathrm{~A} / 1 \mathrm{~B}}$ receptors, which couple to a variety of second messenger systems $(14,34)$. The anti-convulsant effects of agmatine have been found to be associated with its effects on $\alpha_{2 A} R_{S}$ in addition to NMDARs and NO in PTZ induced seizures $(14,22)$. In contrast to this effect, the $\alpha_{2 A} R_{S}$ agonist clonidine inhibits the release of noradrenaline, and it has been reported that this leads to increased incidence and duration of SWDs in a dose-dependent manner in WAG/Rij rats (13). On the contrary, the $\alpha_{2 A} R_{S}$ antagonist atipamezole is reported to cause a dose-dependent suppression of SWD activity in GAERS rats (11). The effects of agmatine on the convulsive vs. absence seizures in opposite directions, in terms of suppressing convulsive seizures in contrast to aggravating absence seizures, may depend on this mechanism associated with the $\alpha_{2 A} R_{S}$. Finally, activation of $5-H T_{1 A}$ receptors by receptor agonists or increase in endogenous 5-HT concentration has been reported to cause dose depen- dent increase in the cumulative duration and number of spike-wave discharges while ICV injection of 5- $\mathrm{HT}_{1 \mathrm{~A}}$ receptor agonist causes dose dependent increase in WAG/Rij rats $(12,35)$. Hence, the agmatine effect on $5-\mathrm{HT}_{1 \mathrm{~A}}$ receptors may also contribute to its aggravating activity on SWDs.

In contrast to the above mentioned mechanisms, however, agmatine can act as an NMDAR antagonist and NOS inhibitor $(14,20)$. These effects would be expected to result in the suppression rather than aggravation of the SWDs as both competitive and non-competitive antagonists of NMDARs reduce the number of SWDs in WAG/Rij rats $(10,36)$. To the contrary, injections of NMDA increase the number of SWDs (10). Additionally, agmatine inhibits all isoforms of NOS, and reduces production of the neuromodulator $N O(19,20)$, and it is known that $\mathrm{NO}$ donors and biological precursor of NO increase the incidence of SWDs in WAG/Rij rats whereas inhibitors of neuronal NOS decrease the number of SWDs $(37,38)$. While agmatine is known as a potent NMDAR antagonist and NOS inhibitor, the report on that $5-\mathrm{HT}_{1 \mathrm{~A}}$ receptor agonists counterbalance the decrease in number and duration of SWDs caused by NMDA antagonists (35), point to the importance or weight of other mechanisms in SWD generation. Within such a framework, present findings may indicate that agmatine's effects at high doses on multiple other receptor types including the 5-HT ${ }_{1 A}, \alpha_{2 A} R_{S}$ and AMPARs dominate those of the NMDARs and NOS inhibition on SWD generation.

Summing up, the present study shows that the higher doses of agmatine temporarily and slightly increase the incidence of SWDs in WAG/Rij rats, which may suggest its possible aggravating activity in absence epilepsy patients through its activity on adrenergic, serotonergic and AMPA receptors.

Ethics Committee Approval: This study was approved by the Kocaeli University Animal Experiments Local Ethics Committee (KOU-HAYDEK 2/3-2010).

Peer Review: Externally peer-reviewed.

Author Contributions: Conception/Design of Study- Ö.A., T.U., F.A., N.A., A.K.; Data Acquisition- Ö.A., A.K.; Data Analysis/lnterpretation- Ö.A.; Drafting Manuscript- Ö.A.; Critical Revision of Manuscript- T.U., F.A., N.A., A.K.; Final Approval and Accountability Ö.A., T.U., F.A., N.A., A.K.

Conflict of Interest: Authors declared no conflict of interest.

Financial Disclosure: This study was supported by grants from the Scientific Research Projects Coordination Unit of Kocaeli University (Project number: 2014/102HD). 


\section{REFERENCES}

1. van Luijtelaar G, Onat FY, Gallagher MJ. Animal models of absence epilepsies: what do they model and do sex and sex hormones matter? Neurobiol Dis 2014;72PtB:167-79. [CrossRef]

2. van Luijtelaar G, Zobeiri M. Progress and outlooks in a genetic absence epilepsy model (WAG/Rij). Curr Med Chem 2014;21(6):704-21. [CrossRef]

3. Smyk MK, van Luijtelaar G. Circadian Rhythms and Epilepsy: A Suitable Case for Absence Epilepsy. Front Neurol 2020;11 245. 2020/04/28. [CrossRef]

4. Russo E, Citraro R, Constanti A, Leo A, Lüttjohann A, van Luijtelaar G, et al. Upholding WAG/Rij rats as a model of absence epileptogenesis: Hidden mechanisms and a new theory on seizure development. Neurosci Biobehav Rev 2016;71:388-408. [CrossRef]

5. Moeller F, Stephani U, Siniatchkin M. Simultaneous EEG and $\mathrm{fMRI}$ recordings (EEG-fMRI) in children with epilepsy. Epilepsia 2013;54(6):971-82. [CrossRef]

6. Meeren HK, Pijn JP, Van Luijtelaar EL, Coenen AM, Lopes da Silva FH. Cortical focus drives widespread corticothalamic networks during spontaneous absence seizures in rats. J Neurosci 2002;22(4):1480-95. [CrossRef]

7. Polack PO, Guillemain I, Hu E, Deransart C, Depaulis A, Charpier S. Deep layer somatosensory cortical neurons initiate spike-and-wave discharges in a genetic model of absence seizures. J Neurosci 2007;27(24):6590-9. [CrossRef]

8. Cope DW, Di Giovanni G, Fyson SJ, Orbán G, Errington $A C$, Lorincz $M L$, et al. Enhanced tonic GABAA inhibition in typical absence epilepsy. Nat Med 2009;15(12):1392-8. [CrossRef]

9. Citraro R, Russo E, Gratteri S, Di Paola ED, Ibbadu GF, Curinga $C$, et al. Effects of non-competitive AMPA receptor antagonists injected into some brain areas of WAG/Rij rats, an animal model of generalized absence epilepsy. Neuropharmacology 2006;51(6):1058-67. [CrossRef]

10. Peeters BW, van Rijn CM, Vossen JM, Coenen AM. Involvement of NMDA receptors in non-convulsive epilepsy in WAG/Rij rats. Life Sci 1990;47(6):523-9. [CrossRef]

11. Yavuz M, Aydın B, Çarçak N, Akman Ö, Raci Yananlı H, Onat F. Atipamezole, a specific $\alpha$. Epilepsia 2020;61(12):2825-35. [CrossRef]

12. Jakus R, Graf M, Juhasz G, Gerber K, Levay G, Halasz P, et al. 5-HT2C receptors inhibit and 5-HT1A receptors activate the generation of spike-wave discharges in a genetic rat model of absence epilepsy. Exp Neurol 2003;184(2):964-72. [CrossRef]

13. Sitnikova E, van Luijtelaar G. Reduction of adrenergic neurotransmission with clonidine aggravates spike-wave seizures and alters activity in the cortex and the thalamus in WAG/Rij rats. Brain Res Bull 2005;64(6):533-40. [CrossRef]

14. Neis VB, Rosa PB, Olescowicz G, Rodrigues ALS. Therapeutic potential of agmatine for CNS disorders. Neurochem Int 2017;108:318-31. [CrossRef]

15. Piletz JE, Aricioglu F, Cheng JT, Fairbanks CA, Gilad VH, Haenisch B, et al. Agmatine: clinical applications after 100 years in translation. Drug Discov Today 2013;18(17-18): 88093. [CrossRef]

16. Uzbay TI. The pharmacological importance of agmatine in the brain. Neurosci Biobehav Rev 2012;36(1):502-19. [CrossRef]
17. Galgano F, Caruso M, Condelli N, Favati F. Focused review: agmatine in fermented foods. Front Microbiol 2012;3:199. [CrossRef]

18. Weng XC, Gai XD, Zheng JQ, Li J. Agmatine blocked voltage-gated calcium channel in cultured rat hippocampal neurons. Acta Pharmacol Sin 2003;24(8):746-50.

19. Galea E, Regunathan S, Eliopoulos V, Feinstein DL, Reis DJ. Inhibition of mammalian nitric oxide synthases by agmatine, an endogenous polyamine formed by decarboxylation of arginine. Biochem J 1996;316(Pt 1):247-9. [CrossRef]

20. Barua S, Kim JY, Kim JH, Lee JE. Therapeutic Effect of Agmatine on Neurological Disease: Focus on lon Channels and Receptors. Neurochem Res 2019;44(4):735-50. [CrossRef]

21. Aricioglu F, Kan B, Yillar O, Korcegez E, Berkman K. Effect of agmatine on electrically and chemically induced seizures in mice. Ann N Y Acad Sci 2003;1009:141-6. [CrossRef]

22. Demehri S, Homayoun H, Honar H, Riazi K, Vafaie K, Roushanzamir F, et al. Agmatine exerts anticonvulsant effect in mice: modulation by alpha 2-adrenoceptors and nitric oxide. Neuropharmacology 2003;45(4):534-42. [CrossRef]

23. Aricioglu F, Altunbas $H$. Is agmatine an endogenous anxiolytic/antidepressant agent? Ann N Y Acad Sci 2003;1009:136-40. [CrossRef]

24. Akman O, Gulcebi MI, Carcak N, Ketenci Ozatman S, Eryigit $\mathrm{T}$, Moshé $\mathrm{SL}$, et al. The role of the substantia nigra pars reticulata in kindling resistance in rats with genetic absence epilepsy. Epilepsia 2015;56(11):1793-802. [CrossRef]

25. Paxinos G, Watson C. The Rat Brain in Stereotaxic Coordinates. 6th ed ed.: Elsevier, 2007.

26. Akman $O$, Karson A, Aker RG, Ates N, Onat FY. Perirhinal cortical kindling in rats with genetic absence epilepsy. Neuroscience Letters 2010;479(1):74-8. [CrossRef]

27. Akman $O$, Demiralp $T$, Ates $N$, Onat FY. Electroencephalographic differences between WAG/ Rij and GAERS rat models of absence epilepsy. Epilepsy Research 2010;89(2-3):185-93. [CrossRef]

28. Rigoulot MA, Boehrer A, Nehlig A. Effects of topiramate in two models of genetically determined generalized epilepsy, the GAERS and the Audiogenic Wistar AS. Epilepsia 2003;44(1):14-9. [CrossRef]

29. Smyk MK, Coenen AM, Lewandowski MH, van Luijtelaar G. Endogenous rhythm of absence epilepsy: relationship with general motor activity and sleep-wake states. Epilepsy Res 2011;93(2-3):120-7. [CrossRef]

30. Peeters BW, Ramakers GM, Vossen JM, Coenen AM. The WAG/Rij rat model for nonconvulsive absence epilepsy: involvement of nonNMDA receptors. Brain Res Bull 1994;33(6):709-13. [CrossRef]

31. Russo E, Citraro R, De Fazio S, Marra R, Gitto R, Chimirri A, et al. Enhancement of anti-absence effects of ethosuximide by low doses of a noncompetitive alpha-amino-3-hydroxy5-methyl-4-isoxazolepropionic acid (AMPA) receptor antagonist in a genetic animal model of absence epilepsy. Epilepsy Behav 2008;13(2):295-9. [CrossRef]

32. Kennard JT, Barmanray R, Sampurno S, Ozturk E, Reid CA, Paradiso $L$, et al. Stargazin and AMPA receptor membrane expression is increased in the somatosensory cortex of Genetic Absence Epilepsy Rats from Strasbourg. Neurobiol Dis 2011;42(1):48-54. [CrossRef] 
33. Neis VB, Moretti M, Bettio LE, Ribeiro CM, Rosa PB, Gonçalves FM, et al. Agmatine produces antidepressantlike effects by activating AMPA receptors and mTOR signaling. Eur Neuropsychopharmacol 2016;26(6):959-71. [CrossRef]

34. Dias Elpo Zomkowski A, Oscar Rosa A, Lin J, Santos AR, Calixto JB, Lúcia Severo Rodrigues A. Evidence for serotonin receptor subtypes involvement in agmatine antidepressant like-effect in the mouse forced swimming test. Brain Res 2004;1023(2):253-63. [CrossRef]

35. Filakovszky J, Gerber K, Bagdy G. A serotonin-1A receptor agonist and an $\mathrm{N}$-methyl-D-aspartate receptor antagonist oppose each others effects in a genetic rat epilepsy model. Neurosci Lett 1999;261(1-2):89-92. [CrossRef]
36. Ramakers GM, Peeters BW, Vossen JM, Coenen AM. CNOX, a new non-NMDA receptor antagonist, reduces spike wave discharges in the WAG/Rij rat model of absence epilepsy. Epilepsy Res 1991;9(2):127-31. [CrossRef]

37. Gunes H, Ozdemir E, Arslan G. Coenzyme Q10 increases absence seizures in WAG/Rij rats: The role of the nitric oxide pathway. Epilepsy Res 2019;154:69-73. [CrossRef]

38. Przewlocka B, Lason W, van Luijtelaar G, Coenen T, Przewlocki R. The role of nitric oxide in genetic model of absence epilepsy in rats. Neuroscience Research Communications Article 1996;18(2):125-31. [CrossRef] 